Article

\title{
Perceived Authenticity and Experience Quality in Intangible Cultural Heritage Tourism: The Case of Kunqu Opera in China
}

\author{
Wenwen $\mathrm{Lu}^{1}{ }^{1}$, , Yongjun $\mathrm{Su}^{1, *}$, Sitan $\mathrm{Su}^{2}$, Jie Zhao ${ }^{3} \mathbb{D}$ and Li Zhang ${ }^{4}$ \\ 1 Joint Institute of Ningbo University and University of Angers/Donghai Academy, Ningbo University, \\ Ningbo 315211, China; cczulww@163.com \\ 2 Faculty of Social Sciences, University of Macau, Taipa, Macau SAR 999078, China; sc12257@umac.mo \\ 3 School of Economics and Management, Inner Mongolia Normal University, Hohhot 010022, China; \\ liying0zhao@163.com \\ 4 School of International Studies, Zhejiang Business Technology Institute, Ningbo 315012, China; \\ 10823039@zjbti.net.cn \\ * Correspondence: suyongjun7312@163.com or suyongjun@nbu.edu.cn; Tel.: +86-137-3615-5289
}

Citation: Lu, W.; Su, Y.; Su, S.; Zhao, J.; Zhang, L. Perceived Authenticity and Experience Quality in Intangible Cultural Heritage Tourism: The Case of Kunqu Opera in China. Sustainability 2022, 14, 2940. https:/ / doi.org/10.3390/su14052940

Received: 1 February 2022 Accepted: 28 February 2022 Published: 3 March 2022

Publisher's Note: MDPI stays neutral with regard to jurisdictional claims in published maps and institutional affiliations.

Copyright: (C) 2022 by the authors. Licensee MDPI, Basel, Switzerland. This article is an open access article distributed under the terms and conditions of the Creative Commons Attribution (CC BY) license (https:// creativecommons.org/licenses/by/ $4.0 /)$.

\begin{abstract}
In the era of the experience economy, intangible cultural heritage (ICH) is now much a richer in terms of authenticity, which largely enriches the tourist experience. This study aims to apply authenticity theory to the field of intangible cultural heritage tourism (ICHT) and to analyze the relationship between the dual dimensions of tourists' perceived authenticity (constructivism and existentialism) and experience quality and satisfaction. A total of 302 valid questionnaires were collected and analyzed using structural equation modeling through a survey of Kunqu Opera, a World ICH in China. The results of this study confirm that the dual dimensions of authenticity (constructive and existential) have significantly different effects on experience quality and satisfaction. Furthermore, with regard to the mediating effect of experience quality, experience quality plays a partially mediating role between existential authenticity and satisfaction. However, constructive authenticity is a positive influence on satisfaction through existential authenticity and experience quality. This article is concluded with a discussion on the theoretical and managerial implications.
\end{abstract}

Keywords: intangible cultural heritage (ICH); intangible cultural heritage tourism (ICHT); perceived authenticity; experience quality; satisfaction; Kunqu Opera

\section{Introduction}

Intangible cultural heritage ( $\mathrm{ICH})$ is a traditional cultural expression that has been formed, developed and passed on by generations of people in the course of human historical practices. It is rich in content and takes a wide range of forms, including: (1) oral traditions and expressions; (2) performing arts; (3) social practices, rituals, festivals and celebrations; (4) knowledge and practices concerning nature and the universe; and (5) traditional handicrafts. Thus, it can be said that ICH is an important object of study that is historical, cultural, inherited and experiential in nature. As a novel and unusual economy [1], the era of the experience economy provides a good context for the development of ICH. The experience economy era arose after the agricultural, industrial and service economies [2], when the economy developed to a point where it was used to drive the social economy towards a balance between material and psychological needs. In the era of the experience economy, ICH is rapidly becoming an important resource for cultural heritage tourism as it has a unique selling point $[3,4]$. ICH is an important part of human civilization [5] and carries the memory of history. It has a unique role in enriching cultural diversity and human creativity [6] and has a high economic and research value. ICHT is a form of cultural tourism consumption based on the development of intangible heritage resources. The current trend in cultural tourism is shifting from tangible heritage to intangible heritage [7]. In the market environment where culture and tourism are integrated, 
'intangible cultural heritage + tourism' has become a new way of developing cultural tourism in various countries.

However, ICH is a cultural form created by a specific group of people within a given time and space. It is the product of people's past practices, interpreting and transmitting information from the past. Additionally, nowadays, along with the development of tourism, $\mathrm{ICH}$ needs to be given a new contemporary meaning to meet its tourism needs. Modern use is different from past use in that it needs to be interpreted through reuse [8]. Thus, there seems to be a contradiction between authenticity and commercialization. One argument is that authenticity, a key principle for the sustainability of cultural heritage tourism [9], is often threatened by this commercialization [10]. However, due to the living nature of $\mathrm{ICH}$ itself, changes and reinventions to its authenticity are inevitable if it is to survive in modern society. Archaeological methods can provide evidence for the evolution of the authenticity of ICH [11]. As humans have evolved, so have the tools and techniques we use, and their original materials are being replaced by new and better ones. The results of such commercialization will not change the essence of $\mathrm{ICH}$, but may instead become a driving force for its preservation and transmission. The 8500-year history of pottery production in Anatolia proves this, and failure to keep up with the times presents a danger of extinction [12].The conservation of ICH is largely dependent on tourism, with the economic benefits of tourism being the main support [13]. Commercial tourism products are a sustainable way of preserving ICH [14]. This study argues that ICH requires physical objects as carriers, but unlike the authenticity of tangible cultural heritage, the authenticity of ICH seems to be less about whether its physical objects are the original versions and more about whether its expression forms continue its cultural connotations. For this reason, the process of commercialization of ICH is in line with the development with time. There is not a complete opposition between authenticity and commercialization, but a dynamic balance between the two.

ICH has a natural link with tourism due to its diversity and uniqueness. Today, tourism experiences have become an increasingly strong psychological need. In such a context, experiencing ICH may become a driving force for sustainable tourism development [13]. A growing number of scholars believe that the core of developing cultural heritage tourism is tourist experience [15]. However, the lack of authenticity caused by over-commodification can accelerate the demise of $\mathrm{ICH}$, and in addition, imperfect forms of tourism development can reduce the attractiveness of ICH and lead to tourists' experiences of ICH being of poor quality [16]. There are not many existing studies that explore the relationship between authenticity and experience quality [17-19]. However, existing research has well established that experience quality can significantly and positively influence tourist satisfaction. Furthermore, previous studies have argued that tourists' perceived authenticity has a direct impact on satisfaction. However, most of the aforementioned studies have focused on the field of tangible cultural heritage, and the findings are not representative in the field of $\mathrm{ICH}$. The relationship between perceived authenticity and satisfaction in the field of ICH still needs to be explored in depth. One important reason for this is the greater importance of experience in the ICHT process. Although experience quality is widely discussed in the tourism literature, the mediating role of experience quality is still not fully explored, especially in the context of ICHT.

The term ICH does not have a long history, although it has been passed down from generation to generation. Influenced by the Authorized Heritage Discourse constructed by UNESCO and ICOMOS, the definition of cultural heritage at the time focused only on tangible cultural heritage [20]. It was not until 2003, when UNESCO adopted the Convention for the Safeguarding of the Intangible Cultural Heritage, that the intangible dimension of cultural heritage was officially recognized [21].In summary, this study addresses these knowledge gaps by attempting to further explore the relationship between authenticity, experience quality and tourist satisfaction in the context of ICHT, based on the premise of tourism commodification. To achieve the research objectives, this study proposes a research model to validate the relationship between authenticity, experience quality and 
tourist satisfaction, and more importantly, the structural model constructed in this study starts with a dual perspective of perceived authenticity (constructive and existential authenticity) to achieve a better understanding of the authenticity of ICH. In addition, this paper highlights a relationship that has not been previously studied in tourism, namely the intrinsic causal relationship between this dual perspective and the experience quality. The proposed research model is then tested and validated by selecting Kunqu Opera, China's first world ICH, as the subject of the study, and by conducting a survey at the Master-of-Nets Garden in Suzhou, China, a typical scenic spot for the commercialization of Kunqu Opera. Finally, the results of this study can provide not only useful theoretical references but also relevant management insights for the authorities in charge of ICH in the process of tourism development.

\section{Literature Review}

\subsection{Authenticity}

The earliest conceptions of authenticity in tourism studies were understood from an objectivist perspective, arguing that authenticity could be measured by absolute, objective criteria, a pure, original and authentic version [22-25]. The original concept of authenticity emphasized the absence of commodification as a key factor in discerning authenticity [26]. Under this logical premise, objective authenticity has two main characteristics: (i) it is associated with a tangible object, essentially emphasizing the static physical nature of heritage [27]; , and (ii) it is judged independently by experts, rather than perceived by tourists [28]. For example, the tree-ring pattern (the chronological characteristics of the wood used) of the Iranian national instrument, TAR, is considered a marker for judging its authenticity. In this case, the characteristics of objective authenticity fit with material culture [29].

Objectivists' standards of authenticity are too strict for most ordinary tourists [30]. On this basis, the introduction of constructive authenticity initiated a shift from the tour object to the tourist subject. Constructivists see authenticity as a socially constructed process and outcome that is negotiable, relative and mutable [30,31]. It is a symbolic sense of authenticity [32] and is a commonly accepted constructivist (commodified) concept by marketers [4]. It is believed that constructive authenticity overcomes the static nature of objectivist authenticity by emphasizing the difference of the subject based on a focus on object authenticity, providing a rationale for commodification.

Building on this, researchers have taken their analysis a step further and proposed a subjective authenticity that is completely independent of the object, namely existential authenticity [25]. It is a self-judgement [33], a personal or intersubjective feeling that can be produced or activated through tourism activities [25,33]. Reisinger and Steiner [28] even suggest that we should abandon the various conceptualizations in favor of a unified existential authenticity. It has been suggested that aesthetic judgements of tourism, consisting of, for example, authenticity, facilitate experiential consumption [34]. Indeed, the existentialists' approach to research places more emphasis on the identity of tourists and their experiences, which is a deepening of the constructivists' ideas about authenticity. In a way, it is also a process of change in the understanding of the 'authenticity' of heritage, a subjectivisation of authenticity. It represents a fundamental paradigm shift from the objective attributes of material culture to the subjective experience of the tourist [6,27].

In summary, as the concept of heritage expands from the tangible to the intangible [7,35-37], the perspective of authenticity research gradually shifts from objective, static and material to subjective, dynamic and immaterial, and therefore the authenticity of materialism or objectivism existing in the field of ICH is considered inappropriate. The authenticity of ICH is the result of the interaction between the cultural values of $\mathrm{ICH}$ and the beliefs of individuals and their representations [3]. For example, if the celebrations of the Pythian Games in ancient Greece have continued to the present day, according to their astronomical traditions, then by using the Antikythera Mechanism it is possible to calculate that the next celebration will be on Thursday 24 August 2023 [38]. 


\subsection{Experience Quality}

In essence, the concept of experience quality in tourism research comes from the analysis of models of product and service quality in the field of service marketing. In fact, in the tourism context, service quality and experience quality are not equivalent. Service quality models such as the SERVQUAL model [39] focus on the technical and functional aspects of service delivery, but ignore the emotional or hedonic disposition of the consumer. However, with the advent of the experience economy, people are no longer buying products and services for functional reasons alone, but for a series of psychologically memorable events [40]. Further, experience quality refers to the psychological outcome of a tourist's participation in a tourism activity [41-43]. Many researchers have argued that assessing tourists' experience quality provides a better understanding of the experiential aspects and emotional responses to tourism activities [44-46].

With regard to the components of experience quality, Otto and Ritchie's [47] research was seminal in that they developed an experience quality scale with four factors, namely hedonics, peace of mind, involvement, and recognition. Scholars subsequently proposed a three-factor [42] or four-factor [40] experience quality scale, depending on their research context. Chen and Chen's [43] study went further, pioneering the application of the concept of experience quality to heritage tourism research and proposing three dimensions of experience quality: involvement, peace of mind, and educational experience. Their study is enlightening, but the concept of heritage here focuses on tangible heritage and is not considered applicable to the context of ICHT. It is worth noting that Kao et al. [48] conceptualized experience quality through four factors, immersion, surprise, participation, and fun, in their study of theme parks. This scale was subsequently further validated by scholars in the context of water park tourism [44], ICHT [49] and green city tourism [50], respectively. In the current study, we adopted Kao et al.'s [48] scale, which is universal and applicable to ICHT research.

\subsection{Tourist Satisfaction}

The concept of tourist satisfaction can be traced back to customer satisfaction in the field of marketing. Today, the variable of satisfaction is widely studied in the tourism field $[18,51]$. Numerous studies have shown that tourist satisfaction stimulates tourists' purchasing behavior, increases their loyalty and their intention to revisit [43,44,51-53] and is critical to the survival, growth and success of tourism [54]. In the early literature on tourist satisfaction, most scholars refer to theories from the field of marketing. According to the 'Expectation-Disconfirmation' model proposed by the American scholar Oliver [55], satisfaction in tourism can be understood as the difference between expectations and performance before and after consumption as perceived by tourists. Dissatisfaction occurs when the post-tour experience falls below the expected level [55], while tourists are satisfied when the post-tour experience exceeds the expected level [43].

This theoretical model was widely used to guide research on measuring tourist satisfaction for quite a while in the time that follows. Indeed, the expectation-disconfirmation model was originally used to measure consumer satisfaction with functional consumer goods in general. In the era of the experience economy, tourists buy experiences, so the measurement of tourist satisfaction should also measure satisfaction with the experience and the emotional experience of the tourist. Therefore, the expectation-disconfirmation model does not fully capture tourist satisfaction. It is a key component of measuring satisfaction, but not the whole picture. Tourist satisfaction should be assessed on multiple dimensions to avoid the errors caused by using a single measurement item [56]. Given this, the relationship between the cost and expected return (benefit) spent by tourists is also used to assess tourist satisfaction. A destination is worthwhile if tourists receive the benefits or value of the trip for their time, effort and money, and vice versa [56]. In addition to this, satisfaction with the tourist experience represents an overall comprehensive evaluation and satisfaction with the entire experience of the consumption process [48]. Tourists evaluate whether a trip is overall satisfactory based on the actual experience. 


\section{Developing Research Hypotheses and Model}

\subsection{Authenticity and Satisfaction}

In previous work, many scholars have studied the causal relationship between authenticity and tourist satisfaction from a cultural heritage tourism perspective $[9,16-18,52,53,57,58]$. Most studies show that those tourists who perceive higher levels of authenticity also achieve higher levels of satisfaction. Among them, Girish and Chen [52] and Lu et al. [9] studied the direct impact of existential authenticity on cultural tourist satisfaction. Nguyen and Cheung [58] used four dimensions to measure the variable of authenticity to study the impact on satisfaction. Some scholars also considered two types of authenticity, objective and existential authenticity [17,18]. Notably, Tian et al. [16] and Park et al. [53], as well as Shen et al. [59] and Zhang and Yin [60], also analyze the effect of constructive authenticity on existential authenticity. Among them, Tian et al. [16] and Park et al. [53] also analyzed the influence of taking authenticity as two and four variables on tourist satisfaction.

Unlike tangible cultural heritage, an entirely static and materially oriented objective authenticity is considered inappropriate in the context of ICH. Therefore, this study considers two perspectives of authenticity, namely constructive and existential. In order to verify that our data confirm the results obtained from the above-mentioned study and to deepen our understanding of these relationships, we propose the following hypotheses:

Hypothesis 1 (H1). The higher the constructive authenticity that the ICH tourists perceive, the higher their level of satisfaction.

Hypothesis 2 (H2). The higher the existential authenticity that the ICH tourists perceive, the higher their level of satisfaction.

Hypothesis 3 (H3). The higher the constructive authenticity that the ICH tourists perceive, the higher their level of the existential authenticity.

\subsection{Authenticity and Experience Quality}

MacCannell [23] argued that all tourists seek authenticity, which he considered to be an authentic, rewarding and spontaneous travel experience [57]. In heritage tourism, authenticity is an important component of a meaningful experience [9]. There are some findings in the existing literature on the relationship between authenticity and experience quality. For example, studies by several scholars confirm that perceived authenticity as a one-dimensional variable has a positive impact on experience quality $[49,61]$. Similarly, Girish and Chen [52] argue that authenticity is a one-dimensional subjective authenticity and confirmed a positive impact on tourists' holiday experience (e.g., emotions). Of course, some scholars have also divided authenticity into two variables, objective and existential authenticity, showing that both can have a direct and positive impact on the experience quality, respectively $[17,18]$. In contrast to the previous study, Zhang et al. [19] used three dimensions of authenticity-objective, constructive and existential-and successfully confirmed that authenticity is the dominant factor in the tourism experience and an important antecedent variable influencing the flow experience.

This study considers both constructive and existential authenticity in the context of $\mathrm{ICH}$, and based on the previous studies mentioned above, it is reasonable to assume that both can have a positive impact on the tourist's experience quality, hence the following hypothesis:

Hypothesis 4 (H4). The higher the constructive authenticity that the ICH tourists perceive, the higher the level of experience quality they have.

Hypothesis 5 (H5). The higher the existential authenticity that the ICH tourists perceive, the higher the level of experience quality they have. 


\subsection{Experience Quality and Satisfaction}

Satisfaction is an emotional state of the overall tourist experience [55]. Tourists assess whether desired tourism expectations are met based on the actual experience [62]. Indeed, the relationship between experience quality and tourist satisfaction has been extensively studied [17,18,42-44,48,51,62]. These studies suggest that experience quality has a positive or direct impact on tourist satisfaction, which means tourists who achieve higher levels of experience quality also achieve higher levels of satisfaction, and conversely, a lower experience quality for tourists leads to lower satisfaction. In order to verify whether the data from this study support the results obtained from previous studies, the following hypothesis is proposed:

Hypothesis 6 (H6). The higher the experience quality that the ICH tourists perceive, the higher the level of satisfaction they have.

\subsection{The Mediating Effects}

Tourist satisfaction in heritage tourism is usually dependent on the comprehensive experience [43] and tourists' perception of authenticity [63]. A study by Domínguez-Quintero et al. [17] not only reveals that experience quality in objective authenticity and satisfaction played a mediating role, but also showed that experience quality also mediated between existential authenticity and satisfaction. More notably, the study found that objective authenticity had a positive effect on satisfaction through existential authenticity and experience quality. Consequently, the authenticity of cultural heritage as perceived by tourists can improve the quality of heritage tourism $[9,30,63]$, thus further increasing the level of tourist satisfaction [49]. However, in the context of ICHT, perceived authenticity is seen as constructive and existential authenticity, and objective authenticity has limitations in exploring tourists' perspectives and motivations due to the lack of an ontological perspective [25,28]; thus, all these arguments lead us to explicitly state the following hypothesis:

Hypothesis 7 (H7). Via experience quality, the constructive authenticity positively influences satisfaction.

Hypothesis 8 (H8). Via experience quality, the existential authenticity positively influences satisfaction.

Hypothesis 9 (H9). Via existential authenticity and via experience quality, the constructive authenticity positively influences satisfaction.

Therefore, the research model is proposed based on the discussions of all the research hypotheses (see Figure 1).

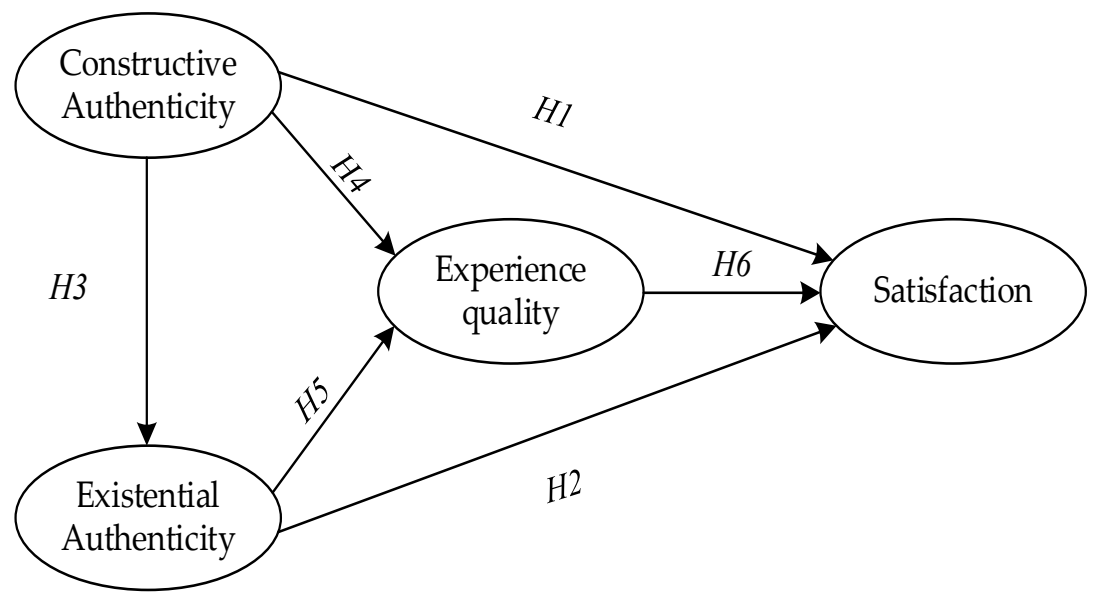

Figure 1. The proposed research model. 


\section{Method}

\subsection{Research Object}

China is rich in ICH resources. To date, 42 of China's ICH items have been inscribed on UNESCO's Representative List of the Intangible Cultural Heritage of Humanity, making it the country with the most ICH in the world. Notably, China's Kunqu Opera was first inscribed in 2001, marking the entry of China's ICH onto the world stage [64]. As an outstanding representative of traditional Chinese theatre, a Kunqu Opera performance is a comprehensive art that includes singing, reciting, acting, playing and dancing, which makes it highly enjoyable and experiential. In addition, as the 'ancestor of a hundred operas', Kunqu Opera is one of the oldest surviving theatre genres in China [6]. Its longstanding historical heritage has allowed its authenticity to remain in its most essential form in the midst of commercialization. Therefore, this study, which takes Kunqu Opera as the object, is typical and representative in the study of authenticity in ICHT and the experience quality of tourists.

\subsection{Measures}

To ensure the validity of the content, the questionnaire for this study referred to validated English scales from previous studies. Given that the survey was targeted at Chinese tourists, this questionnaire was eventually developed in Chinese on a reference basis. The scales were then translated forward and backward by professional translators and assessed by the researcher to ensure the accuracy of the measurement. On the basis of the above, a pilot survey questionnaire was developed. The main body of the questionnaire was divided into five sections: the first four parts were about the measurement of four variables, all constructs were assessed on a 7-point Likert scale ranging from 1 (strongly disagree) to 7 (strongly agree), and the results of the indicator measures were analyzed using structural equation modeling. The fifth section reports information on the respondents, for which a demographic analysis was performed. In Table 1, the relevant sources for the scale adaptation of each variable are presented in detail. We distributed 76 questionnaires to tourists as a pilot survey using convenience sampling at the end of May 2021 in the Master-of-Nets Garden and obtained 62 valid questionnaires. Based on the results of the analysis of the questionnaire data and the actual situation at the case sites, the questionnaire was modified to remove the participation dimension of experience quality.

Table 1. Scale adaptation.

\begin{tabular}{cc}
\hline Variables & Source \\
\hline Constructive authenticity & Kolar and Zabkar (2010) [65]; Park et al. (2019) [53] \\
Existential authenticity & Kolar and Zabkar (2010) [65]; Domínguez-Quintero et al. (2018) [17] \\
Experience quality & Kao et al. (2008) [48]; Jin et al. (2015) [44]; Su et al. (2020) [49] \\
Satisfaction & Oliver (1980) [55]; Yoon and Uysal (2005) [56]; \\
& Domínguez-Quintero et al. (2018) [17] \\
\hline
\end{tabular}

\subsection{Research Site}

This case study took place in the Master-of-Nets Garden in Suzhou, Jiangsu Province, China. The Master-of-Nets Garden was chosen as the case research site for two reasons: Firstly, Kunqu Opera has become a typical cultural symbol of Suzhou. As the birthplace of Kunqu Opera, Suzhou has made the preservation and inheritance of Kunqu Opera an important part of its cultural construction, and has a large number of venues for the preservation, inheritance, promotion and performance of Kunqu Opera. Secondly, among the many performance venues, Kunqu Opera performances at the Master-of-Nets Garden are unique. On the one hand, they break through the constraints of time and space, with performances taking the form of mobile immersion experiences, which take place in the commercialized scenic area at night. On the other hand, several ICHs, including Kunqu Opera, are combined in the performance. The Kunqu Opera performances here are usually 
excerpts from some classical repertoires (e.g., Dream in the Deserted Garden) and are shorter than traditional Kunqu Opera performances. In view of this, the Kunqu Opera performances at the Master-of-Nets Garden are more commercial in nature than other Kunqu Opera performance venues, and more in line with our study.

\subsection{Data Collection}

Due to time and manpower constraints, we conducted a formal questionnaire survey via convenience sampling in mid-July 2021 at the Master-of-Nets Garden, which was targeted at tourists to the site after the Kunqu Opera performance. We took a one-to-one approach and asked them if they would like to participate in the questionnaire. Each respondent took about six minutes to complete the survey. A total of 415 questionnaires were administered. In structural equation modeling, the sample size should be at least 100 or 200 [66], with a typical sample size of approximately 200 [67], and the sample size should be at least five times the number of items measured [68]. In this study, 21 items were used to construct the structural equation model, with a final sample size of 302 and a recovery rate of $72.77 \%$, which met the requirements of the study.

\subsection{Data Analysis}

IBM SPSS Statistics 26 and Amos Graphics 26 were used as analytical tools in this study. Firstly, descriptive analyses of demographics and travel profiles were conducted on the final valid sample using SPSS 26, followed by reliability tests to ensure the reliability of each dimension. Next, confirmatory factor analysis (CFA) was conducted with Amos 26 to validate the combined reliability and convergent validity as well as the discriminant validity of the measurement model through the values of factor loadings (FL), average variance extracted (AVE), and composite reliability (CR). The overall structural model was then tested to discriminate the model fit as well as to test each hypothesized path, and finally the Bootstrap method was used to analyze possible mediating effects using 5000 Bootstrap re-samples and 95\% bias-corrected and percentile confidence intervals (CI).

\section{Results}

\subsection{Respondent Profiles}

Table 2 provides a demographic profile of the sample. As for the gender of respondents, $58.9 \%$ were female and $41.1 \%$ were male. As regards the age, the majority of respondents were 24 years old and below (36.1\%) and between 26 and 35 years old (35.4\%), followed by between 36 and 45 years old (23.2\%). With respect to education, the vast majority of respondents had completed college or university $(54.6 \%)$ or graduate school and beyond $(35.4 \%)$. Moreover, more than half of the respondents $(61.9 \%)$ were visiting for the first time, and the rest were repeat tourists. Respondents' occupations were mostly government staff $(30.1 \%)$ and students (26.5\%), with employee (19.9\%) following closely behind.

Table 2. Demographic and travel profile.

\begin{tabular}{cccc}
\hline Variables & Category & Frequency Counts & Percentage (\%) \\
\hline \multirow{2}{*}{ Gender } & Male & 124 & 41.1 \\
& Female & 178 & 58.9 \\
\hline \multirow{2}{*}{ Age } & $<25$ & 109 & 36.1 \\
& $26-35$ & 107 & 35.4 \\
& $36-45$ & 13 & 23.2 \\
& $46-55$ & 3 & 4.3 \\
\hline
\end{tabular}


Table 2. Cont.

\begin{tabular}{|c|c|c|c|}
\hline Variables & Category & Frequency Counts & Percentage $(\%)$ \\
\hline \multirow{4}{*}{ Frequency } & First time & 187 & 61.9 \\
\hline & Second time & 49 & 16.2 \\
\hline & Third time & 17 & 5.6 \\
\hline & More than three times & 49 & 16.2 \\
\hline \multirow{5}{*}{ Accompany } & Individual traveler & 42 & 13.9 \\
\hline & Family & 131 & 43.4 \\
\hline & Friends & 109 & 36.1 \\
\hline & Group tour & 5 & 1.7 \\
\hline & Others & 15 & 5.0 \\
\hline \multirow{4}{*}{ Education } & Middle school and below & 7 & 2.3 \\
\hline & $\begin{array}{c}\text { Technical secondary school } \\
\text { or high school }\end{array}$ & 23 & 7.6 \\
\hline & College or undergraduate & 165 & 54.6 \\
\hline & Master degree or above & 107 & 35.4 \\
\hline \multirow{6}{*}{ Profession } & Employee & 60 & 19.9 \\
\hline & Government staff & 91 & 30.1 \\
\hline & Businessman & 4 & 1.3 \\
\hline & Student & 80 & 26.5 \\
\hline & Freelance & 36 & 11.9 \\
\hline & Others & 31 & 10.3 \\
\hline \multirow{5}{*}{$\begin{array}{l}\text { Monthly income } \\
\text { (RMB yuan) }\end{array}$} & $<3000$ & 69 & 22.8 \\
\hline & $3001-5000$ & 46 & 15.2 \\
\hline & $5001-8000$ & 69 & 22.8 \\
\hline & $8001-10,000$ & 38 & 12.6 \\
\hline & $>10,000$ & 80 & 26.5 \\
\hline
\end{tabular}

\subsection{Measurement Model}

First, this study examined the Cronbach's alpha values for each dimension and the results were all greater than the critical value of 0.7 [69] and ranged from 0.844 to 0.937 (see Table 3), which met the criteria for this study, indicating that the data reliability for each dimension was good and showed good internal consistency, so it is possible to proceed to the next step of the analysis. The measurement model was tested using CFA, which, according to Anderson and Gerbing [70], specifies the relationship between the observed measures and the underlying constructs they assume and allows the constructs to freely interrelate with each other. Six latent variables (constructive authenticity, existential authenticity, immersion, surprise, fun, and satisfaction) and 25 items were included in the measurement model. Then, we removed four items with high cross-loadings and low factor scores, and finally retained 21 items. From the results in Table 3, the factor loadings (FL) of each latent variable corresponding to each question ranged from 0.704 to 0.933 , all of which were greater than 0.7 , indicating their high representativeness. In addition, the average variance extracted (AVE) of each latent variable ranged from 0.601 to 0.794 , all of which were greater than 0.5 , and the composite reliability (CR) ranged from 0.846 to 0.939 , all of which were greater than 0.7 , indicating convergence is satisfactory [71,72]. In addition, the square root of each latent variable AVE was higher than the correlation between that latent variable and the other latent variables (see Table 4), indicating the ideal discriminant validity of the scale data $[71,72]$. 
Table 3. The result of confirmatory factor analysis $(n=302)$.

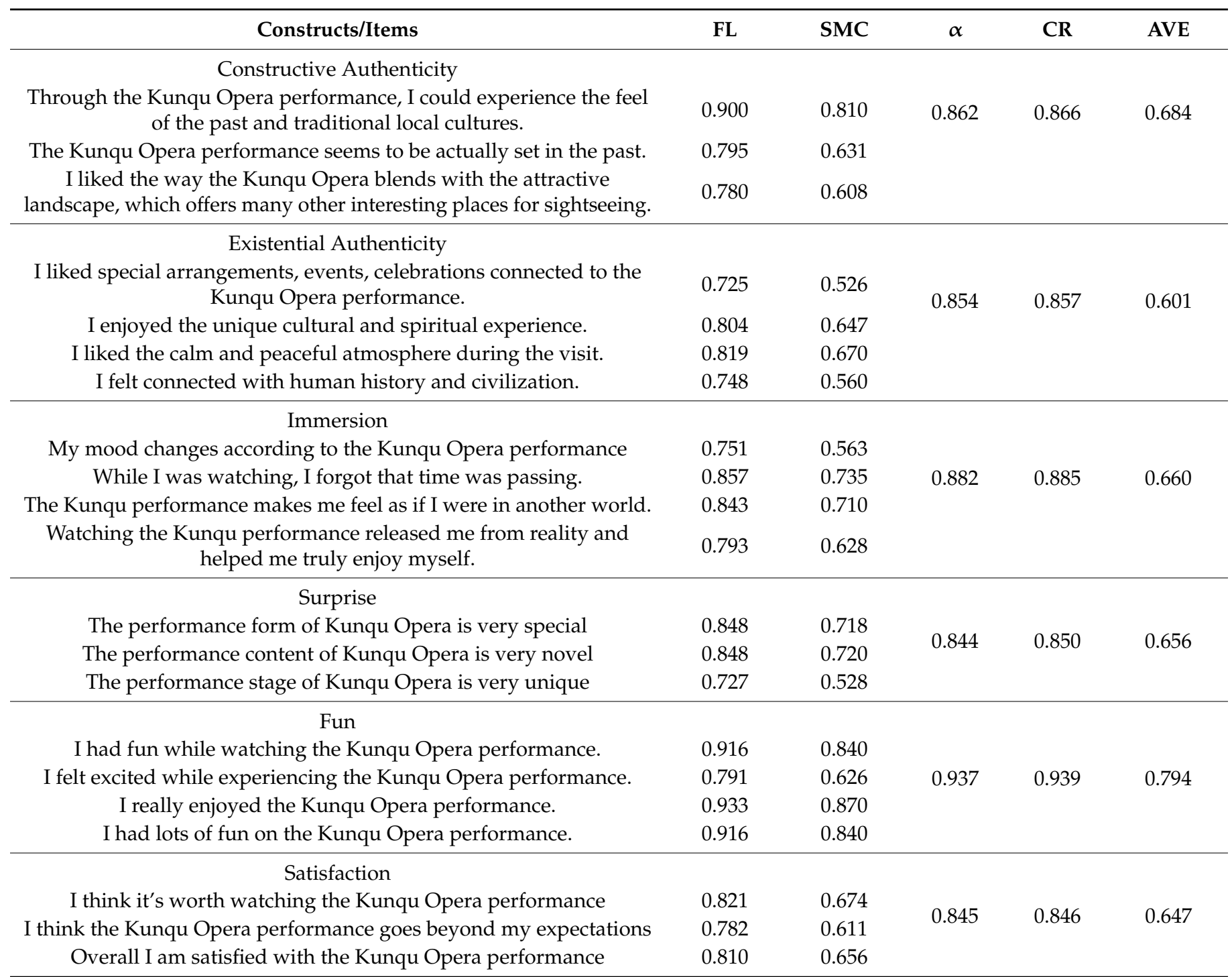

Note: FL = Factor loading; SMC = squared multiple correlation; $\alpha=$ Cronbach's $\alpha ; C R=$ composite reliability; $\mathrm{AVE}=$ average variance extracted .

Table 4. Discriminant validity.

\begin{tabular}{cccccccc}
\hline Constructs & AVE & CA & EA & IM & SU & FU & SA \\
\hline CA & $\mathbf{0 . 6 8 4}$ & $\mathbf{0 . 8 2 7}$ & & & & & \\
EA & $\mathbf{0 . 6 0 1}$ & 0.674 & $\mathbf{0 . 7 7 5}$ & & & \\
IM & $\mathbf{0 . 6 6 0}$ & 0.460 & 0.629 & $\mathbf{0 . 8 1 2}$ & & \\
SU & $\mathbf{0 . 6 5 6}$ & 0.323 & 0.490 & 0.439 & $\mathbf{0 . 8 1 0}$ & \\
FU & $\mathbf{0 . 7 9 4}$ & 0.449 & 0.573 & 0.713 & 0.453 & $\mathbf{0 . 8 9 1}$ & \\
SA & $\mathbf{0 . 6 4 7}$ & 0.414 & 0.661 & 0.720 & 0.596 & 0.770 & $\mathbf{0 . 8 0 4}$ \\
\hline
\end{tabular}

Note: Square roots of AVE are shown on the diagonal in bold.

\subsection{Structural Model and Hypothesis Testing}

Given the acceptable convergent and discriminant validity, tests of the structural model constitute a confirmatory assessment of nominal validity [70]. The model fit indexes (Table 5 provides the results of the CFA and structural model fit measures) $\left(\chi^{2} / \mathrm{df}=1.702\right.$, RMSEA $=0.048, \mathrm{RMR}=0.034, \mathrm{GFI}=0.951, \mathrm{CFI}=0.981, \mathrm{IFI}=0.981, \mathrm{TLI}=0.974)$ were 
all within acceptable ranges, indicating a good fit between the model and the observed data [72]. Therefore, the structural model and hypothesis can be tested. The structural model was estimated by applying the maximum likelihood (ML) method. Figure 2 shows the path of the structural model used in this study. As shown in Table 6, H2, H3, H5 and $\mathrm{H} 6$ were supported, but $\mathrm{H} 1$ and $\mathrm{H} 4$ were rejected. This indicates that constructive authenticity only has a significant positive effect on existential authenticity, that both existential authenticity and experience quality have a significant positive effect on satisfaction, and that existential authenticity also has a significant positive effect on experience quality.

Table 5. Results of the model fit measures.

\begin{tabular}{cccccccc}
\hline Index & $\chi^{2} / \mathbf{d f}$ & RMSEA & RMR & GFI & CFI & IFI & TLI \\
\hline CFA & 1.864 & 0.054 & 0.042 & 0.908 & 0.966 & 0.966 & 0.959 \\
Structural model & 1.702 & 0.048 & 0.034 & 0.951 & 0.981 & 0.981 & 0.974 \\
\hline
\end{tabular}

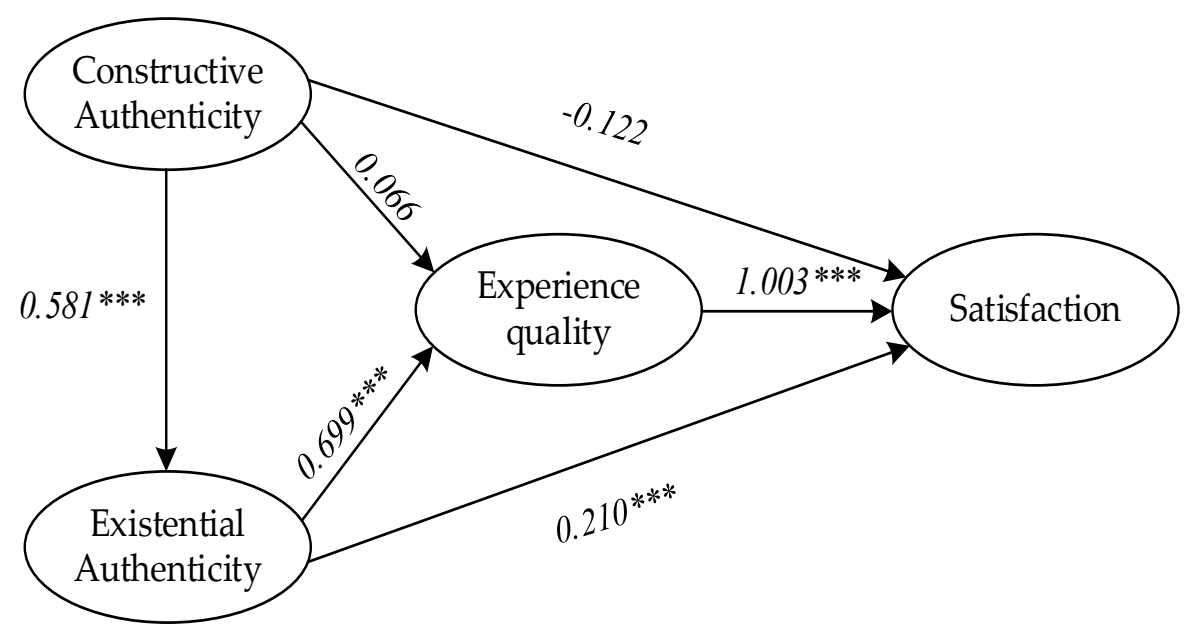

Figure 2. Structural equation model results. Note: ${ }^{* * *} p<0.001$. Significant means the value of $p$ is less than 0.05 .

Table 6. Results of structural equation modeling analysis.

\begin{tabular}{ccccc}
\hline Hypothesis Path & Estimate & S.E. & $p$-Value & Result \\
\hline H1: Constructive Authenticity $\rightarrow$ Satisfaction & -0.122 & 0.066 & 0.066 & Rejected \\
H2: Existential Authenticity $\rightarrow$ Satisfaction & 0.210 & 0.060 & $* * *$ & Supported \\
H3: Constructive Authenticity $\rightarrow$ Existential Authenticity & 0.581 & 0.061 & $* * *$ & Supported \\
H4: Constructive Authenticity $\rightarrow$ Experience Quality & 0.066 & 0.074 & 0.372 & Rejected \\
H5: Existential Authenticity $\rightarrow$ Experience Quality & 0.699 & 0.099 & $* * *$ & Supported \\
H6: Experience Quality $\rightarrow$ Satisfaction & 1.003 & 0.123 & $* * *$ & Supported \\
\hline
\end{tabular}

\footnotetext{
Note: ${ }^{* * *} p$-value $<0.001$.
}

\subsection{Testing for Mediating Effects}

The Bootstrap method is currently the ideal test for mediating effects [73-75]. If the confidence interval for the resulting indirect effect estimate $\left(a^{*} b\right)$ does not contain 0 then it is judged to be significant. Following the mediation analysis procedure proposed by Zhao et al. [76], the Bootstrap mediation variable test was conducted with a sample size of 5000 and a $95 \%$ confidence interval, following the multi-step mediation variable test proposed by Hayes et al. [75] and Hayes [77]. As shown in Table 7, the results indicate that the indirect effect consisting of $\mathrm{H} 7$ was 0.065 , with a Bootstrap $95 \%$ confidence interval of $(-0.013,0.144)$, containing 0 , indicating that the mediating role of quality of experience in constructive authenticity and satisfaction was not significant. The indirect effect consisting 
of H8 was 0.419 , with a Bootstrap 95\% confidence interval of $(0.324,0.517)$, containing no 0 , indicating a significant mediating role for experience quality in existential authenticity and satisfaction. H9 comprised an indirect effect of 0.220 , Bootstrap $95 \%$ confidence interval $(0.157,0.284)$, containing no 0 , indicating a significant mediating role for existential authenticity and experience quality in the constructive authenticity and satisfaction chain.

Table 7. Mediation hypothesis testing.

\begin{tabular}{cccccc}
\hline \multirow{2}{*}{ Mediation Hypotheses } & Effect & BootSE & \multicolumn{3}{c}{ Bias-Corrected Percentile 95\%CI } \\
\cline { 4 - 5 } & & & BootLLCI & BootULCI & Result \\
\hline $\mathrm{H} 7: \mathrm{CA} \rightarrow \mathrm{EQ} \rightarrow \mathrm{SA}$ & 0.065 & 0.040 & -0.013 & 0.144 & Rejected \\
$\mathrm{H} 8: \mathrm{EA} \rightarrow \mathrm{EQ} \rightarrow \mathrm{SA}$ & 0.419 & 0.049 & 0.324 & 0.517 & Supported \\
$\mathrm{H} 9: \mathrm{CA} \rightarrow \mathrm{EA} \rightarrow \mathrm{EQ} \rightarrow \mathrm{SA}$ & 0.220 & 0.033 & 0.157 & 0.284 & Supported \\
\hline
\end{tabular}

\section{Discussion}

In recent years, with the rise of ICHT in many countries, its investigation has received much academic attention and research on ICH has increased significantly [15]. From the promulgation of relevant laws and regulations on $\mathrm{ICH}$ to the formulation of a national, provincial, municipal and county-level protection system, $\mathrm{ICH}$ in China is receiving increasing attention. However, given the nascent nature of the research, experimental evidence on authenticity, experience quality and satisfaction in the field of ICH is currently very limited. Therefore, this study uses Kunqu Opera, a world ICH in Suzhou, China, to explore the mechanisms of influence between the three through empirical research. With this aim in mind, this study tests a structural model that incorporates four constructs: constructive authenticity, existential authenticity, experience quality and tourist satisfaction. The analysis of the structural model has led to the following discussion based on the findings of the study.

\subsection{Main Findings}

Our study finds that only existential authenticity was able to significantly influence tourist satisfaction, and this effect of constructive authenticity was not significant. This finding differs from the majority of previous studies $[17,18,52,58]$, who argue that authenticity can positively influence tourist satisfaction. At the same time, this finding is also different from the few studies that have concluded that there is no direct effect of authenticity on tourist satisfaction $[9,78]$.

This study uses a dual dimension (constructive and existential authenticity) to examine the concept of authenticity in depth and finds that constructive authenticity can positively influence tourists' existential authenticity, which supports previous scholars' views $[53,59,60]$. This result suggests that feelings and experiences of existential authenticity are constructed in social processes and can therefore be understood under constructive authenticity [79]. In addition, this study explores a relationship that has not been previously studied in tourism, namely the impact of this dual dimension on the experience quality. The findings suggest that constructive authenticity has no direct impact on experience quality, while existential authenticity can significantly and positively influence experience quality.

This study also further confirms the important impact of experience quality on satisfaction, which supports the views of previous scholars [17,18,42-44,48,51,62]. The experience quality is the psychological outcome of the tourist's involvement in the tourism activity and is the antecedent variable of satisfaction, so it can be said that satisfaction is the fulfillment response of the tourist after the tourism experience.

The mediating role in this study's model suggests that existential authenticity positively influences satisfaction through experience quality. However, constructive authenticity can only positively influence satisfaction through existential authenticity and experience quality. Tourist perceived authenticity forms the psychological perception of tourist participation in tourism activities through the process of first-hand experience. The experience 
quality is key to driving tourist satisfaction, and a high-quality tourism experience can significantly increase tourist satisfaction with ICHT.

\subsection{Managerial Implications}

The findings of this paper have important managerial implications for managers and marketers of ICH. Firstly, the dual dimension of ICH authenticity (constructive and existential authenticity) constructed in this study has a distinctly dynamic character, which is in line with the core concept of change in the definition of ICH [37]. Based on this characteristic, it needs to engage and cross-fertilize with modernity to enable the values of heritage to be realized in the present and in the future [14]. The commercialization of tourism may be an integral form in this dynamic process [80]. Therefore, managers and marketers of ICH should always focus on sustainability, and can change and adapt its presentation to a certain extent without destroying the essence of ICH. For example, adjusting the performance time (e.g., shortening the performance time or changing it to an evening performance, etc.), combining a variety of ICH (e.g., Kunqu Opera, Suzhou Pingtan and Suzhou embroidery) in a joint performance, incorporating modern elements into ICH performances (e.g., traditional theatre with modern dance), etc. This helps to make it understandable and accessible to tourists who are new to this ICH and creates more interest in ICH for tourists. In addition, similar to the adoption of new materials with improved properties for tangible cultural heritage [81], ICH can also adopt modern science and technology. For example, the combination of high-tech special effects lighting and holography in this study of Kunqu Opera as a means of performing to tourists has been given a new lease of life through modern use in order to achieve sustainable development strategies.

Secondly, according to the research findings, constructive authenticity as perceived by visitors has a positive impact on existential authenticity, while existential authenticity has a positive direct impact on both the experience quality and satisfaction. Managers, marketing planners and policy makers of ICH should be concerned with the construction of authenticity. Tourists' perceptions of constructive authenticity also need to be based on a certain level of originality. Therefore, it is necessary to create a traditional style of ICH as a whole through folklore performances, exhibitions, cultural relics and information signs, and also through professional and lively guided tours that allow tourists to perceive the local past and traditional local culture. In addition to this, the integration of ICH into a fascinating scenic area can be drawn from the fusion of Kunqu Opera and the Master-ofNets Garden in this study, which not only creates a unique cultural and spiritual experience and a calm and peaceful atmosphere, but also allows tourists to feel a connection to human history and civilization, resulting in a more meaningful and enjoyable experience.

Thirdly, experience quality mediates between tourists' perceived authenticity and satisfaction, while the positive impact of the experience quality on satisfaction has been proven. In other words, in the context of $\mathrm{ICH}$, the value of an $\mathrm{ICH}$ product comes from the tourist's experience. The experience quality plays a leading role in the formation of tourist satisfaction, which requires managers, marketing planners and developers of ICH to take steps to improve tourists' experience quality. They can be able to innovate design concepts, attract tourists with new and unique themes, and provide creative and surprising ICH content through technology and digital forms of expression. For example, the theatres of the Eastern Mediterranean used acoustic simulation software to devise new ways of using the theatre space through the use of virtual reality, 3D modeling and animation [8]. This measure avoids the problem of echoes and ultimately improves the sound reflections from the orchestra floor. High acoustic standards are achieved through modern technological means, which improves the quality of the acoustic experience for theatregoers, allowing them to fully participate in the event or performance and thus immerse themselves in the enjoyment and pleasure of consumption. All these factors contribute to a good tourist experience and ultimately induce a high level of tourist satisfaction. 


\section{Conclusions}

ICH can be integrated with tourism through appropriate strategies, and moderate means of commercialisation are in line with the development of the experience economy. However, how this new form of development strategy can make ICH sustainable is a formidable challenge. According to the above discussion, if ICH is to be effectively and permanently integrated into tourism activities, it needs to be developed to enrich its authenticity and enhance tourist experience quality. This is a key management principle for the sustainable development of ICH. Tourists are the mainstay of the tourism experience economy, and the effective commercialisation of ICH relies on tourists' understanding of the nature of $\mathrm{ICH}$ during the experience as a means of promoting the sustainable development of ICH. Under the strong development momentum of the ICHT economy, taking authenticity as the solid foundation, experience quality as the driving force and sustainable development as the ultimate goal will help ICH to play a greater economic value and research value.

The results of this study contribute to our understanding of the context of ICHT and expand knowledge in this area. The results of this study also contribute to the knowledge system. Firstly, this paper discusses the relationship between authenticity, experience quality and satisfaction in the same research framework, which is rarely found in past studies. On the one hand, the dual dimension of authenticity is investigated in terms of its different effects on experience quality and satisfaction. On the other hand, the positive mediating effect of experience quality between authenticity and satisfaction is also verified. The related findings improve and extend existing research. Existential authenticity involves internal satisfaction, while constructive authenticity is an external projection of expectations [82]. The different authenticity perceived by tourists in the field of ICH can vary through the expectation differences generated by the experience. Secondly, most of the existing literature on experience quality is based on the context of tangible cultural heritage tourism. However, this study is one of the few literatures that focuses on experiential quality within the field of ICHT, which enriches the context of experiential quality research. Distinguished from tangible cultural heritage, ICH is not a simple material object but a living performance [3], an intangible and living heritage. As such, ICHT places greater emphasis on the process of hands-on experience for tourists, and experience quality plays an integral role in understanding the meaning of ICH and its transmission.

This study is not perfect, and there are several limitations that researchers should take into account when evaluating the results. First of all, according to the definition in the Intangible Heritage Convention adopted by UNESCO, ICH includes five types. This study only examined Kunqu Opera in the performing arts category. However, each type of ICH has its own unique and specific attributes. Therefore, the universality of the findings of this study needs to be further verified, and future research needs to verify the generalizability of the proposed model to other types of ICH. Secondly, this study only collected the perceptions about Kunqu Opera from tourists who visited the Night Tour of The Master-of-Nets Garden in Suzhou, China. In general, tourists to ICH tourism in other regions or countries may have a different view about Kunqu Opera. Therefore, future studies should be applied to other regions or countries with caution and need to consider differences in visitor perceptions due to the presence of cultural or regional issues. Finally, the experience quality scale in this study mainly draws from Kao et al. [48], and although the scale has been validated in several domains with good reliability and validity, the scale has rarely been applied by scholars to ICHT research. Therefore, for future research, we suggest the development of scales specifically for the ICH domain to more comprehensively and accurately reflect all aspects of the experience quality in ICHT. Furthermore, future studies could probably contribute to our knowledge in this field by investigating the same framework in different Asian countries and other continents, and these studies may contribute more to ICHT, authenticity theory, tourist experience theory, etc. 


\begin{abstract}
Author Contributions: Conceptualization: Y.S. and W.L.; methodology: W.L. and S.S.; software: W.L.; validation: Y.S. and S.S.; formal analysis: W.L. and S.S.; investigation: Y.S. and S.S.; resources: W.L. and S.S.; data curation: W.L. and L.Z.; writing—original draft preparation: W.L. and J.Z.; writingreview and editing: W.L., L.Z., J.Z. and S.S.; visualization: W.L. and J.Z.; supervision: Y.S.; project administration: Y.S.; funding acquisition: Y.S. All authors have read and agreed to the published version of the manuscript.
\end{abstract}

Funding: This research was supported by National Social Science Foundation of China under Grant No.20BH142.

\title{
Institutional Review Board Statement: Not applicable.
}

Informed Consent Statement: Not applicable.

Data Availability Statement: The data presented in this study are available from the authors upon request.

Conflicts of Interest: The authors declare no conflict of interest. The funders had no role in the design of the study; in the collection, analyses, or interpretation of data; in the writing of the manuscript, or in the decision to publish the results.

\section{References}

1. Toffler, A. Future Shock; Bantam House: New York, NY, USA, 1970.

2. Pine, B.J.; Gilmore, J.H. Welcome to the Experience Economy. Harv. Bus. Rev. 1998, 76, 97-105. [PubMed]

3. Kim, S.; Whitford, M.; Arcodia, C. Development of intangible cultural heritage as a sustainable tourism resource: The intangible cultural heritage practitioners' perspectives. J. Hérit. Tour. 2019, 14, 422-435. [CrossRef]

4. Chhabra, D. Authenticity and the authentication of heritage: Dialogical perceptiveness. J. Hérit. Tour. 2019, 14, 389-395. [CrossRef]

5. Poria, Y.; Butler, R.; Airey, D. The core of heritage tourism. Ann. Tour. Res. 2003, 30, 238-254. [CrossRef]

6. Ruggles, D.F.; Silverman, H. Intangible Heritage Embodied; Springer: New York, NY, USA, 2009.

7. Richards, G. Cultural tourism: A review of recent research and trends. J. Hosp. Tour. Manag. 2018, 36, 12-21. [CrossRef]

8. Haddad, N.A.; Fakhoury, L.A. Conservation and preservation of the cultural heritage of ancient theatres Andodeain the Eastern Mediterranean. Stud. Conserv. 2010, 55, 18-23. [CrossRef]

9. Lu, L.; Chi, C.G.; Liu, Y. Authenticity, involvement, and image: Evaluating tourist experiences at historic districts. Tour. Manag. 2015, 50, 85-96. [CrossRef]

10. Cohen, E. Authenticity, Equity and Sustainability in Tourism. J. Sustain. Tour. 2002, 10, 267-276. [CrossRef]

11. Liritzis, I.; Laskaris, N.; Vafiadou, A.; Karapanagiotis, I.; Volonakis, P.; Papageorgopoulou, C.; Bratitsi, M. Archaeometry: An overview. Sci. Cult. 2020, 6, 49-98.

12. Ünal, S. Ceramic production from neolithic Doğanhisar pottery culture: Intangible heritage of technology transfer from past to present. Sci. Cult. 2021, 7, 77-91.

13. Esfehani, M.H.; Albrecht, J.N. Roles of intangible cultural heritage in tourism in natural protected areas. J. Hérit. Tour. 2016, 13, 15-29. [CrossRef]

14. Olalere, F.E. Intangible Cultural Heritage as Tourism Product: The Malaysia Experience. Afr. J. Hosp. Tour. Leis. 2019, 8, 1-10.

15. Su, X.; Li, X.; Kang, Y. A Bibliometric Analysis of Research on Intangible Cultural Heritage Using CiteSpace. SAGE Open 2019, 9 , 1-18. [CrossRef]

16. Tian, D.; Wang, Q.; Law, R.; Zhang, M. Influence of Cultural Identity on Tourists' Authenticity Perception, Tourist Satisfaction, and Traveler Loyalty. Sustainability 2020, 12, 6344. [CrossRef]

17. Domínguez-Quintero, A.M.; González-Rodríguez, M.R.; Paddison, B. The mediating role of experience quality on authenticity and satisfaction in the context of cultural-heritage tourism. Curr. Issues Tour. 2018, 23, 248-260. [CrossRef]

18. Domínguez-Quintero, A.M.; González-Rodríguez, M.R.; Roldán, J.L. The role of authenticity, experience quality, emotions, and satisfaction in a cultural heritage destination. J. Hérit. Tour. 2019, 14, 491-505. [CrossRef]

19. Zhang, S.-N.; Li, Y.-Q.; Liu, C.-H.; Ruan, W.-Q. How does authenticity enhance flow experience through perceived value and involvement: The moderating roles of innovation and cultural identity. J. Travel Tour. Mark. 2019, 36, 710-728. [CrossRef]

20. Haddad, N.A.; Fakhoury, L.A.; Sakr, Y.M. A critical anthology of international charters, conventions \& principles on documentation of cultural heritage for conservation, monitoring \& management. Mediterr. Archaeol. Archaeom. 2021, 21, 291-310.

21. Melis, C.; Chambers, D. The construction of intangible cultural heritage: A Foucauldian critique. Ann. Tour. Res. 2021, 89, 103206. [CrossRef]

22. Maccannell, D. Staged Authenticity: Arrangements of Social Space in Tourist Settings. Am. J. Sociol. 1973, 79, 589-603. [CrossRef]

23. Maccannell, D. The Tourist: A New Theory of Leisure Class; Schocken: New York, NY, USA, 1976.

24. Boorstin, D.J. The Image: A Guide to Pseudo-Events in America; Atheneum: New York, NY, USA, 1964.

25. Wang, N. Rethinking Authenticity in Tourism Experience. Ann. Tour. Res. 1999, 26, 349-370. [CrossRef]

26. Cornet, J. African Art and Authenticity. Afr. Arts 1975, 9, 52-55. [CrossRef] 
27. Su, J. Conceptualising the subjective authenticity of intangible cultural heritage. Int. J. Hérit. Stud. 2018, 24, 919-937. [CrossRef]

28. Reisinger, Y.; Steiner, C.J. Reconceptualizing object authenticity. Ann. Tour. Res. 2006, 33, 65-86. [CrossRef]

29. Soltani, M.; Pourtahmasi, K.; Mohammadi, M. Checking the originality of TAR musical instrument by using dendrochronology. Sci. Cult. 2021, 7, 1-12.

30. Cohen, E. Authenticity and commoditization in tourism. Ann. Tour. Res. 1988, 15, 371-386. [CrossRef]

31. Bruner, E.M. Abraham Lincoln as Authentic Reproduction: A Critique of Postmodernism. Am. Anthropol. 1994, 96, 397-415. [CrossRef]

32. Culler, J. Semiotics of Tourism. Am. J. Semiot. 1981, 1, 127-140. [CrossRef]

33. Steiner, C.J.; Reisinger, Y. Understanding existential authenticity. Ann. Tour. Res. 2006, 33, 299-318. [CrossRef]

34. Kirillova, K.; Fu, X.; Lehto, X.; Cai, L. What makes a destination beautiful? Dimensions of tourist aesthetic judgment. Tour. Manag. 2014, 42, 282-293. [CrossRef]

35. del Barrio, M.J.; Devesa, M.; Herrero, L.C. Evaluating intangible cultural heritage: The case of cultural festivals. City Cult. Soc. 2012, 3, 235-244. [CrossRef]

36. Vecco, M. A definition of cultural heritage: From the tangible to the intangible. J. Cult. Hérit. 2010, 11, 321-324. [CrossRef]

37. Smith, L.J. The Uses of Heritage; Routledge: London, UK, 2006.

38. Efstathiou, K.; Efstathiou, M.; Basiakoulis, A.; Kokkinos, N. Determination of the celebration of the next Pythian games using the Antikythera Mechanism, considering that they are celebrated uninterrupted until today. Sci. Cult. 2022, 8, 81-93.

39. Parasuraman, A.; Zeithaml, V.A.; Berry, L. SERVQUAL: A Multiple-Item Scale for Measuring Consumer Perceptions of Service Quality. J. Retail. 1988, 64, 12-40.

40. Pine, B.J.; Gilmore, J.H. The Experience Economy: Work Is Theatre E Every Business a Stage; Harvard Business School Press: Boston, MA, USA, 1999.

41. Crompton, J.L.; Love, L.L. The predictive validity of alternative approaches to evaluating quality of a festival. J. Travel Res. 1995, 34, 11-24. [CrossRef]

42. Cole, S.T.; Scott, D. Examining the Mediating Role of Experience Quality in a Model of Tourist Experiences. J. Travel Tour. Mark. 2004, 16, 79-90. [CrossRef]

43. Chen, C.-F.; Chen, F.-S. Experience quality, perceived value, satisfaction and behavioral intentions for heritage tourists. Tour. Manag. 2010, 31, 29-35. [CrossRef]

44. Jin, N.P.; Lee, S.; Lee, H. The Effect of Experience Quality on Perceived Value, Satisfaction, Image and Behavioral Intention of Water Park Patrons: New versus Repeat Visitors. Int. J. Tour. Res. 2015, 17, 82-95. [CrossRef]

45. Wu, H.-C.; Ai, C.-H. Synthesizing the effects of experiential quality, excitement, equity, experiential satisfaction on experiential loyalty for the golf industry: The case of Hainan Island. J. Hosp. Tour. Manag. 2016, 29, 41-59. [CrossRef]

46. Schlesinger, W.; Cervera-Taulet, A.; Pérez-Cabañero, C. Exploring the links between destination attributes, quality of service experience and loyalty in emerging Mediterranean destinations. Tour. Manag. Perspect. 2020, 35, 100699. [CrossRef]

47. Otto, J.E.; Ritchie, J.B. The service experience in tourism. Tour. Manag. 1996, 17, 165-174. [CrossRef]

48. Kao, Y.-F.; Huang, L.-S.; Wu, C.-H. Effects of Theatrical Elements on Experiential Quality and Loyalty Intentions for Theme Parks. Asia Pac. J. Tour. Res. 2008, 13, 163-174. [CrossRef]

49. Su, X.; Li, X.; Chen, W.; Zeng, T. Subjective vitality, authenticity experience, and intangible cultural heritage tourism: An empirical study of the puppet show. J. Travel Tour. Mark. 2020, 37, 258-271. [CrossRef]

50. Wang, H.-J. Antecedents of behavioral intentions for green city tourists. Environ. Dev. Sustain. 2021, 24, 377-398. [CrossRef]

51. Altunel, M.C.; Erkurt, B. Cultural tourism in Istanbul: The mediation effect of tourist experience and satisfaction on the relationship between involvement and recommendation intention. J. Destin. Mark. Manag. 2015, 4, $213-221$.

52. Girish, V.G.; Chen, C.-F. Authenticity, experience, and loyalty in the festival context: Evidence from the San Fermin festival, Spain. Curr. Issues Tour. 2017, 20, 1551-1556. [CrossRef]

53. Park, E.; Choi, B.-K.; Lee, T.J. The role and dimensions of authenticity in heritage tourism. Tour. Manag. 2019, 74, 99-109. [CrossRef]

54. Sirakaya, E.; Petrick, J.; Choi, H.-S. The Role of Mood on Tourism Product Evaluations. Ann. Tour. Res. 2004, 31, 517-539. [CrossRef]

55. Oliver, R.L. A Cognitive Model of the Antecedents and Consequences of Satisfaction Decisions. J. Mark. Res. 1980, 17, 460-469. [CrossRef]

56. Yoon, Y.; Uysal, M. An examination of the effects of motivation and satisfaction on destination loyalty: A structural model. Tour. Manag. 2005, 26, 45-56. [CrossRef]

57. Pearce, P.L.; Moscardo, G.M. The Concept of Authenticity in Tourist Experiences. Aust. N. Z. J. Sociol. 1986, 22, 121-132. [CrossRef]

58. Nguyen, T.H.H.; Cheung, C. Chinese heritage tourists to heritage sites: What are the effects of heritage motivation and perceived authenticity on satisfaction? Asia Pac. J. Tour. Res. 2016, 21, 1155-1168. [CrossRef]

59. Shen, S.; Guo, J.; Wu, Y. Investigating the Structural Relationships among Authenticity, Loyalty, Involvement, and Attitude toward World Cultural Heritage Sites: An Empirical Study of Nanjing Xiaoling Tomb, China. Asia Pac. J. Tour. Res. 2014, 19, 103-121. [CrossRef]

60. Zhang, T.; Yin, P. Testing the structural relationships of tourism authenticities. J. Destin. Mark. Manag. 2020, 18, 100485. [CrossRef] 
61. Li, X.; Shen, H.; Wen, H. A Study on Tourists Perceived Authenticity towards Experience Quality and Behavior Intention of Cultural Heritage in Macao. Int. J. Mark. Stud. 2016, 8, 117-123. [CrossRef]

62. Lin, C.-H.; Kuo, B.Z.-L. The Behavioral Consequences of Tourist Experience. Tour. Manag. Perspect. 2016, 18, 84-91. [CrossRef]

63. Chhabra, D.; Healy, R.; Sills, E. Staged authenticity and heritage tourism. Ann. Tour. Res. 2003, 30, 702-719. [CrossRef]

64. Dang, Q.; Luo, Z.; Ouyang, C.; Wang, L.; Xie, M. Intangible Cultural Heritage in China: A Visual Analysis of Research Hotspots, Frontiers, and Trends Using CiteSpace. Sustainability 2021, 13, 9865. [CrossRef]

65. Kolar, T.; Zabkar, V. A consumer-based model of authenticity: An oxymoron or the foundation of cultural heritage marketing? Tour. Manag. 2010, 31, 652-664. [CrossRef]

66. Boomsma, A. The Robustness of LISREL against Small Sample Sizes in Factor Analysis Models. In Systems under Indirect Observation: Causality, Structure, Prediction, Part I; Jöreskog, K.G., Wold, H.H., Eds.; North-Holland: Amsterdam, The Netherlands, 1982.

67. Kline, R.B. Principles and Practice of Structural Equation Modeling; Guilford Press: New York, NY, USA, 2011.

68. Hair, J.F.; Black, W.C.; Babin, B.J.; Anderson, R.E.; Tatham, R.L. Multivariate Data Analysis, 6th ed.; Prentice Hall: New York, NY, USA, 2006

69. Nunnally, J.C.; Bernstein, I.H. Psychometric Theory, 3rd ed.; McGraw-Hill: New York, NY, USA, 1994.

70. Anderson, J.C.; Gerbing, D.W. Structural equation modeling in practice: A review and recommended two-step approach. Psychol. Bull. 1988, 103, 411-423. [CrossRef]

71. Fornell, C.G.; Larcker, D.F. Evaluating structural equation models with unobservable variables and measurement error. J. Mark. Res. 1981, 18, 39-50. [CrossRef]

72. Hair, J.F.; Black, W.C.; Babin, B.J.; Anderson, R.E. Multivariate Data Analysis, 7th ed.; Prentice Hall: New York, NY, USA, 2010.

73. Preacher, K.J.; Hayes, A.F. Asymptotic and resampling strategies for assessing and comparing indirect effects in multiple mediator models. Behav. Res. Methods 2008, 40, 879-891. [CrossRef] [PubMed]

74. Preacher, K.J.; Rucker, D.D.; Hayes, A.F. Addressing Moderated Mediation Hypotheses: Theory, Methods, and Prescriptions. Multivar. Behav. Res. 2007, 42, 185-227. [CrossRef] [PubMed]

75. Hayes, A.F.; Preacher, K.J.; Myers, T.A. Mediation and the Estimation of Indirect Effects in Political Communication Research. In The Sourcebook for Political Communication Research; Bucy, E.P., Holbert, R.L., Eds.; Routledge: New York, NY, USA, 2011.

76. Zhao, X.; Lynch, J.G., Jr.; Chen, Q. Reconsidering Baron and Kenny: Myths and Truths about Mediation Analysis. J. Consum. Res. 2010, 37, 197-206. [CrossRef]

77. Hayes, A.F. Introduction to Mediation, Moderation, and Conditional Process Analysis: A Regression-Based Approach; Guilford Press: New York, NY, USA, 2013.

78. Lee, S.; Phau, I.; Hughes, M.; Li, Y.F.; Quintal, V. Heritage Tourism in Singapore Chinatown: A Perceived Value Approach to Authenticity and Satisfaction. J. Travel Tour. Mark. 2015, 33, 981-998. [CrossRef]

79. Olsen, K. Authenticity as a concept in tourism research: The social organization of the experience of authenticity. Tour. Stud. 2002, 2, 159-182. [CrossRef]

80. $\mathrm{Su}, \mathrm{J}$. Understanding the changing Intangible Cultural Heritage in tourism commodification: The music players' perspective from Lijiang, China. J. Tour. Cult. Chang. 2018, 17, 247-268. [CrossRef]

81. Michalopoulou, A.; Maravelaki-Kalaitzaki, P.N.; Stefanis, N.A.; Theoulakis, P.; Karatasios, I. Evaluation of nanolime dispersions for the protection of archaeological clay-based building materials. Mediterr. Archaeol. Archaeom. 2020, 20, $221-242$.

82. Cook, P.S. Constructions and Experiences of Authenticity in Medical Tourism: The Performances of Places, Spaces, Practices, Objects and Bodies. Tour. Stud. 2010, 10, 135-153. [CrossRef] 